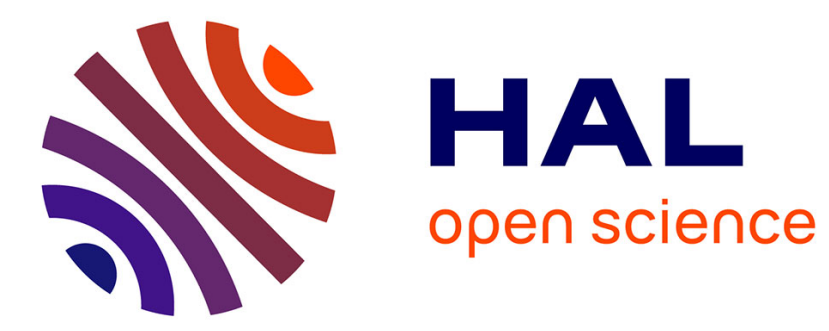

\title{
The organism as ontological go-between: Hybridity, boundaries and degrees of reality in its conceptual history
}

\author{
Charles T. Wolfe
}

\section{- To cite this version:}

Charles T. Wolfe. The organism as ontological go-between: Hybridity, boundaries and degrees of reality in its conceptual history. Studies in History and Philosophy of Science Part C: Studies in History and Philosophy of Biological and Biomedical Sciences, 2014, 48, pp.151-161. 10.1016/j.shpsc.2014.06.006 . hal-01233194

\section{HAL Id: hal-01233194 \\ https://hal.science/hal-01233194}

Submitted on 24 Nov 2015

HAL is a multi-disciplinary open access archive for the deposit and dissemination of scientific research documents, whether they are published or not. The documents may come from teaching and research institutions in France or abroad, or from public or private research centers.
L'archive ouverte pluridisciplinaire HAL, est destinée au dépôt et à la diffusion de documents scientifiques de niveau recherche, publiés ou non, émanant des établissements d'enseignement et de recherche français ou étrangers, des laboratoires publics ou privés. 


\title{
The organism as ontological go-between
}

\section{hybridity, boundaries and degrees of reality in its conceptual history}

\author{
Charles T. Wolfe \\ Centre for History of Science, \\ Department of Philosophy and Moral Sciences \\ Ghent University \\ Blandijnberg 2, B-9000 Ghent \\ charles.wolfe@ugent.be
}

Forthcoming in Studies in History and Philosophy of Biological and Biomedical Sciences

\begin{abstract}
The organism is neither a discovery like the circulation of the blood or the glycogenic function of the liver, nor a particular biological theory like epigenesis or preformationism. It is rather a concept which plays a series of roles - sometimes overt, sometimes masked - throughout the history of biology, and frequently in very normative ways, also shifting between the biological and the social. Indeed, it has often been presented as a key-concept in life science and the 'theorization' of Life, but conversely has also been the target of influential rejections: as just an instrument of transmission for the selfish gene, but also, historiographically, as part of an outdated 'vitalism'. Indeed, the organism, perhaps because it is experientially closer to the 'body' than to the 'molecule', is often the object of quasi-affective theoretical investments presenting it as essential, sometimes even as the pivot of a science or a particular approach to nature, while other approaches reject or attack it with equal force, assimilating it to a mysterious 'vitalist' ontology of extra-causal forces, or other pseudo-scientific doctrines. This paper does not seek to adjudicate between these debates, either in terms of scientific validity or historical coherence; nor does it return to the well-studied issue of the organism-mechanism tension in biology. Recent scholarship has begun to focus on the emergence and transformation of the concept of organism, but has not emphasized so much the way in which organism is a shifting, 'go-between' concept - invoked as 'natural' by some thinkers to justify their metaphysics, but then presented as value-laden by others, over and against the natural world. The organism as go-between concept is also a hybrid, a boundary concept or an epistemic limit case, all of which partly overlap with the idea of 'nomadic concepts'. Thereby the concept of organism continues to function in different contexts - as a heuristic, an explanatory challenge,
\end{abstract}


a model of order, of regulation, etc. - despite having frequently been pronounced irrelevant and reduced to molecules or genes. Yet this perpetuation is far removed from any 'metaphysics of organism', or organismic biology.

\section{Keywords}

Organism, as go-between, organicism, vitalism, mechanism

\section{Introduction}

The organism is neither a discovery like the circulation of the blood or the glycogenic function of the liver, nor a particular biological theory like epigenesis or preformationism. It is rather a concept which plays a series of roles - sometimes overt, sometimes masked - throughout the history of biology, and frequently in very 'valuative' or normative ways, also shifting between the biological and the social (Canguilhem, 2002, Gissis, 2009). Indeed, it has often been presented as a key-concept in life science and the 'theorization' of Life (for instance, in the sense that biology is a science of organisms or is nothing; Grene and Depew, 2004). Similarly, at a more conceptual level, perhaps because it is experientially closer to the 'body' than to the 'molecule', the organism is often the object of quasi-affective theoretical investments presenting it as essential, perhaps even as the pivot of a science or a particular approach to nature (from Hegel onwards, and explicitly with thinkers such as Kurt Goldstein and, with more metaphysical investment, Hans Jonas; see Wolfe, 2004, 2010). Conversely, it has also been the target of some influential rejections, classically in Dawkins' vision of the organism as just an instrument of transmission for the selfish gene (Dawkins, 1976), but also, at a historiographic level, as a denunciation of 'vitalism' in the history of science (Schiller, 1978) or, as Laublicher has noted, in the kinds of attacks that go beyond scientific claims and counter-claims (Laubichler, 2000), assimilating its concept to a mysterious 'vitalist' ontology of non-causal forces, or some other 'pre'- or 'pseudo'-scientific doctrine; or at least, "a highly contestable notion" (Sterelny and Griffiths, 1999, p. 173). Biologists of a reductionist persuasion will target any notion of a 'force', 'principle' or other transcendent ground which causes physical and chemical processes in the body while itself being extra-causal, uncaused, immaterial.

Here, I do not seek to adjudicate between these debates, either in terms of scientific validity or historical coherence; nor do I return to the classic issue of the organism-mechanism tension which has particularly been studied in late nineteenth and early twentieth-century 
biology (Hein, 1972, Allen, 2005). It has been observed that we have numerous histories of genetics, but no history of organism (Laubichler, 2000). We have studies of the emergence and displacements of the term (Cheung, 2006) but not of the shifts in concepts of organism as parts or foundations of a science (Peterson, 2010 is a step in this direction, for twentieth-century organicism). Recent scholarship has begun to focus on the transformation of the concept of organism (Huneman and Wolfe eds., 2010), but there is an aspect that has not been emphasized so much (except perhaps under the heading of 'metaphors of organism' in Schlanger, 1971): the way in which organism is a shifting, 'go-between' concept - invoked as 'natural' by some thinkers to justify their metaphysics, but then presented as value-laden by others over and against the natural world. It can also be described as a hybrid (sometimes expressing a kind of complex mechanistic view, sometimes a foundational subjectivity), a "boundary concept" or "trading zone" (Star and Griesemer, 1989, Galison, 1999). The organism concept also often deliberately shifts, whether we call this a nomadic concept or, in my terms, an ontological go-between, between metaphysical and empirical levels of discussion something that both metaphysicians and historians of biology often miss sight of.

Which hybridity is at issue, and what do I understand by the organism as ontological gobetween? One might think that the former refers to the diversity of its meanings, uses, metaphors and reference points. And indeed, diversity, metaphor and reference all have a distinguished pedigree in our efforts at conceptualizing the history of science. Evelyn Fox Keller has emphasized (with reference to Max Black) that metaphor "can serve important positive functions in scientific explanations" (Keller, 2003, p. 118). She uses the language of productivity: "metaphoric utterances can be scientifically productive just because they open up new perspectives on phenomena that are still obscure and ill-defined and about which clarification is achieved only through a process of groping - in other words, on the kinds of phenomena that scientists take as the objects of their investigations" (ibid.). Yet it is not enough to insist on the presence of metaphors in scientific cognition. Precisely as regards the productivity of concepts such as organism, we need to add at least two further dimensions to Fox Keller's defense of the role of metaphors. A useful further suggestion is Mieke Bal's, that concepts are "tools of intersubjectivity" (Bal, 2002, p. 22); they do more than metaphors, because "they offer miniature theories, and in that guise, help in the analysis of objects, situations, states and other theories" (ibid.).

But if we were to follow this line of thought, we would be completely blind to the polemical dimension of the organism concept: it is much less about consensus and more about trying to insist on something missing from scientific practice. In addition, neither the insistence on the positive role of metaphors in science, nor the focus on "travelling concepts" can yield any sense of the problem of the organism's ontological status, whether in the traditional sense of the organism as biological individual, or the sense of organism as ontological go-between. To 
be fair, Bal seems to identify some aspect of the latter when she speaks of the "propagation of a concept that emerges in one field, in another field that changes its meaning and whose meaning it, in turn, changes, constitutes the primary feature of a concept, both as asset and liability, or risk" (Bal, 2002, p. 32). Yet propagation is still not enough. Because part of the 'gobetween' quality I would like to bring out in what follows, leads us to ask: is the variety of meanings and references of 'organism' an epistemic issue? A confirmation that we should be content to be instrumentalists in science and not ascribe any innate reality to the entities under discussion? And if, in contrast, it enters into ontology, in what sense? I will suggest that we need to include under the heading of the organism's ontological status, both some of its conceptual productivity via its hybridity, and its historical diversity (which typically would serve as an excuse for the instrumentalist to ignore or bracket off ontological considerations). It is a "limit case," not per se an object of inquiry "in the day-to-day operations of the scientist in the laboratory," but rather the reflection, "sometimes quite philosophical, regarding scientific issues that do not adhere to the usual stipulations of empirical warrant. Yet they are issues which scientists feel compelled to make pronouncements regarding them" (Peterson, 2012). Indeed, Peterson mentions, in addition to matter itself, and human cognition, the nature of organisms as one of these limit cases. The concept of organism is never pure or analytically unresolvable. It is always partly constructed or modified or borrowed from elsewhere, including when its asserted in its valuative terms, over and against 'mechanistic science', or 'atomism', 'reductionism' and other equally elastic and often ideological categories. It shifts between realms, but it is also a hybrid in esse.

1.

The hybridity of the concept of organism, which functions alternatively as a polemical concept, a model of order or of regulation, an explanatory challenge, and more broadly, as what I'll call an ontological go-between, can serve as a defense of the concept, by showing that it continues to be productive, as a heuristic, but also precisely as something other than a construct or metaphor, in different contexts despite having frequently been pronounced 'caduc', irrelevant, reduced to molecules or genes. Yet this perpetuation is far removed from any 'metaphysics of organism', or organismic biology. Again, what is perpetuated is not a monolithic, unresolvable or metaphysically foundational individual (the organism as person, one is tempted to say) but a shifting entity. Go-betweenness as understood here is, as Bal says of her "travelling concepts," an "asset rather than a liability" (Bal, 2002, p. 25).

In earlier work on the concept of organism I first made a case for an instrumentalist concept (Wolfe, 2004), which would dissolve ontological debates between reductionist and heavily organismic approaches to the nature or individuality of living beings; more recently 
(Wolfe, 2010) I argued for a weakly ontological view in which organizational concepts, whether primarily structural (the 'animal economy' in Montpellier vitalism) or also homeostatic (as in Claude Bernard and more recently, Alvaro Moreno and William Bechtel's discussion of organizational closure in biological systems), were the 'realest' yet also least ideological concept of organism. While I return to what I'Il call 'weak organicism' in the last sections of this essay, I will be more interested here in these reality claims as part of a broader phenomenon of hybridity, borrowing, transplantation and displacement. In this sense, my approach to 'organism' here treats it less like an absolute, irreducible and trans-historical concept, and more like a varying, plural historical concept but also, a construct with varying degrees of heuristic utility, in that sense closer to 'mechanism' as understood in recent discussions which move away from mechanistic ontology and towards issues such as 'what can mechanisms do?'.

Indeed, one can ask the question of the very existence of the organism, as the journal American Zoologist did a few decades ago - one article in this issue is entitled "Do organisms exist?", Ruse, 1989), or as philosophers and theoretical biologists have more recently (Wolfe, 2004, Cheung, 2006, Huneman and Wolfe, eds., 2010, Toepfer, 2013). This ontological question - does the organism exist or not? or is it just an artefact, an effect or quasi-anthropomorphic projection of the human mind? - derives from the frequent judgment in molecular biology, according to which biology progresses by 'molecularization' (Morange, 1997), which should lead to the disappearance of 'older' concepts such as organism. In reaction, it is often suggested that such concepts have a purely instrumental status, as more or less useful constructs which can be discarded as science progresses. The instrumentalist could say of the organism what Buffon said famously of species, that it is not a natural kind but a 'constructed' category, an "abstract," "general" and temporary construct of the mind, or "vue de l'esprit"1 : a projection onto the world which enables us to grasp it otherwise than as a heap of dead matter or a chaos of atoms in motion; in other words, a heuristic construct. Yet I will treat instrumentalism rather differently here: in less deflationary terms, because I present the historicity of the concept - the historical diversity of organism concepts - as part of the reality of the concept. Paradoxically, this historicization of instrumentalism blurs the instrumentalism / realism divide ${ }^{2}-$ an interesting consequence, but one which then raises the problem of reference.

If I am denying that organism reduces to a random assortment of metaphors, or of historically located practices and meanings, which have nothing to do with another, am I then

\footnotetext{
${ }^{1}$ For Buffon, species is not a natural kind but an "abstract," "general" and temporary construct of the mind ("notre ouvrage") which is the result of comparing individuals to each other (Buffon [1753], "L'âne," pp. 384-385). His successor Lacépède explicitly describes species as a "vue de l'esprit," a mental construct, in his commentary and extension of Buffon's work (Lacépède [1800], "Sur la durée des espèces," p. xxxiii).

${ }^{2}$ Thanks to Anya Plutynski for suggesting this point.
} 
defending a revised version of the old claim (Depew and Grene, 2004) according to which biology is a 'science of organisms', and thinkers and biologists from Aristotle to Lamarck, Darwin, Claude Bernard, Haldane and Needham worked with 'organism' as a referent? If this were so, one could claim that diversity of meanings, practices and contexts could be subsumed under a theory of reference whereby the term 'organism' would "nonetheless refer to the same entity across these theories, so that the theories can potentially make conflicting claims about this common referent" while being comparable (Brigandt, 2010, p. 20). But precisely in the case of 'organism', it is at best unclear what that shared referent would be. As Brigandt notes, even if a term's reference is stable across history, its definition may be subject to change (ibid., p. 20), and here, that kind of stability is not even present.

I am leaving aside the old Aristotelian question of organisms as individual substances, that is, the idea that it is a 'fact', either of our intuition or of nature, that organisms, particularly mid-size entities, represent paradigms for our idea of individuals; as James Lennox puts it, for Aristotle, "paradigm natural substances were not the common material constituents of the universe, but the most active, complex and organized of bodies, the living ones" (Lennox, 2001, pp. 108-109); recent work in biology challenges some of these intuitions, from the work focusing on the role of the bacteria in our gut in maintaining our immunological individuality (Pradeu, 2012) to corals and forests (Bouchard, 2006, 2013). These are fascinating questions, but belong to a separate, specifically metaphysical dimension of the issue. My aim here is not to defend a metaphysical thesis on the nature of biological individuality, or to illustrate its radical denial in favor of evolving scientific change (as in Rosenberg's instrumentalism: Rosenberg, 1989) in some historical cases, despite how the hybridity described here could sound 'instrumentalist'. Rather, I argue for a reality of the organism concept in terms of hybridity and productivity, not just as a temporary instrumental construct with no particular content; "concepts are not just tools" (Bal, 2002, p. 29). What does it mean to inquire into the reality of the organism?

Significant metaphysical theses that could be used in support of an irreducible organism concept include the 'animalism' defended by Eric Olson (in which our personal identity is defined by our biology in the sense that we are 'human animals' more fundamentally than we are Lockean psychological persons defined by the continuity of their thoughts, Olson, 1997) and the form of Aristotelian substantivalism defended by David Wiggins, which invokes "an unmysterious but pre-empiricist notion of substance" (Wiggins, 2001, p. 80). But whether a substrate, a total system of interrelations, or some other 'substance', these theories are competing claims concerning the nature of a real organismic identity. Instead, my analysis tends to show how the organism concept is always borrowed from some other realm (from the metaphysical to the physical or inversely; or from the physical to the biological, or from the 
biological to the social), as a go-between, yet a go-between which serves a genuine purpose of conceptual articulation.

Sometimes, our understanding of individuality or identity of organisms is challenged by Nature itself, so that we should broaden it (e.g. to the concept of superorganism, including the Portuguese man-o-war jellyfish and eusocial insect colonies [Pepper and Heron, 2008, Queller and Strassman, 2009, Haber, 2013]) or loosen it, as in Scott Turner's work on how artificial, abiotic structures such as the termite mound (Turner, 2006, Turner, 2007, ch. 2 and Turner, 2013), and 'natural' organisms such as individual termites together form one homeostatic entity, serving actual physiological functions including maintenance of temperature and respiration. In that sense, to borrow a helpful distinction from Matt Haber, the issue here is less 'are organisms paradigmatic individuals?' and more 'how could we define a paradigmatic organism?' (Haber, 2013, p. 201), with the proviso that my answer will include its shifting character, rather than point to a strict definition. My emphasis on how the concept of organism shifts, circulates and is both 'displacer and displaced' between different scientific and philosophical contexts is, to reiterate, not a defense of organisms as paradigmatic individuals or irreducible wholes, nor conversely, does it present organisms as purely metaphors, linguistic conventions or façons de parler. ${ }^{3}$ Qua real, the organism is more a matter of 'degrees of organismality' (Queller and Strassman, 2009); qua concept, it is both a hybrid (lacking a single 'pure' definition), and a go-between, being perpetually being combined with other concepts from that of soul to that of machine, biochemical process or cybernetic system, from the seventeenth to the twentieth centuries).

2.

From the heyday of psychophysics in the nineteenth century to the triumphant reductionist proclamations of biochemists such as Emil Du Bois-Reymond and Jacques Loeb in the next generations, for whom life had to be a matter of biochemistry (thus Loeb insisted on the unlimited scope of biochemical explanations: "we cannot allow any barrier to stand in the path of our complete control and thereby understanding of vital phenomena" [cit. in Allen, 2005, p. 273; see Loeb, 1964]), we often encounter the assertion that the organism has been replaced by molecular explanations. This replacement is not just the ordinary fading away of one concept in favor of another. Loeb's language of barriers is echoed in a contemporary

\footnotetext{
${ }^{3}$ In that sense, my analysis is located halfway between the aforementioned metaphysical perspective (are organisms, i.e. biological individuals in this context, real? in what sense? As substance, process, interrelation of parts, continuity of consciousness, etc.?) and the study of organisms as metaphors (Schlanger, 1971) or as epistemic things (Rheinberger, 1997a). In trying to articulate precisely this 'between' conceptual space, I have found Brigandt's analysis of epistemic goals and reference and Bal's discussion of travelling concepts, useful.
} 
statement by D'Arcy Thompson, who criticized Haldane for excessive ontological commitments, and insisted implicitly that there is 'nothing other' than physical and chemical reactions: "The alleged phenomena of self-production, self-maintenance, and self-regulation are the common currency of those who, finding the mechanistic theory difficult and unsatisfactory, are content to postulate a something 'which interferes with and guides the physical and chemical reactions'" (D'Arcy Thompson, in Haldane, D'Arcy Thompson et al., 1918, p. 12). It is important to note, though, that such assertions occur in diverse, not particularly homogeneous scientific trajectories: they are not monolithic, nor do they necessarily refer to the same object.

The properly philosophical analogue of these 'empirical' reductionist claims is Ernest Nagel's effort to restate the teleological language of organismic biology in purely mechanistic terms (Nagel, 1961). Sometimes this reduction, elimination or otherwise, erasure of organism is presented in negative terms (as a loss of meaning, a dehumanization, etc.), but more often it is presented as a neutral statement of fact: "both scientists and philosophers take ontological reduction for granted... Organisms are 'nothing but' atoms, and that is that" (Hull, 1981, p. 282), or "Organisms have disappeared as the fundamental units of life. In their place we now have genes ..." (Goodwin 1994, p. 1). Yet such neutral statements sometimes have implicit normative content, namely, recommending that we no longer do revisionary metaphysics of organism, understood as the project of revising our scientific worldpicture to supplement it with something additional (whether this be an 'entelechy', as in Driesch, a 'drive' as in E.S. Russell or an 'organismic law' as in Elsasser).

Historically, we can see this process of demystification at work with the abandonment of questions such as 'What is life?' as "the practical starting point for physiological research" (Coleman, 1977, p. 13), after figures such as Treviranus and Caspar Friedrich Wolff in the early nineteenth century. A further step is taken when, despite the presence and even usefulness of the (or 'an') organism concept in disciplines such as embryology, ethology or evolutionary biology (Pepper and Heron, 2008), some researchers in fundamental biology (Di Paolo, 2009) end up stating that life itself does not exist. This recalls François Jacob's famous pronouncement that Life is no longer an object of empirical research: "We no longer inquire into Life today in laboratories" ("On n'interroge plus la vie aujourd'hui dans les laboratoires": Jacob, 1970, p. 320). More recently, Edouard Machery has argued (Machery, 2012) that we should give up seeking to provide definitions of life, as these are either folk concepts, or unresolvable with other competing definitions: namely, evolutionists, theoretical biologists, self-organization theorists, molecular biochemists and artificial life researchers cannot agree on a definition. 
While Machery's point is well taken, ${ }^{4}$ one could observe (a) that there is a reality to certain life-concepts - I shall speak instead of forms of organization (Bechtel, 2007, Mossio and Moreno, 2010, Moreno and Mossio forthcoming), here, that of organism - and (b) that there is a particular productivity of the organism if it is understood as a go-between, not as some archaic vital substance or irreducible individuality. To be clear, it is not a matter of deciding between 'real or not real'. There have been dozens of papers and volumes defending the reality of organism, often in easily falsifiable ways (whether it is because they rely too much on purported empirical irreducibility, like Elsasser's organismic laws, or because they smuggle in too much metaphysics, like Ruyer's biophilosophy), just as there have been dozens of contributions insisting it is 'dead', refuted, eliminated, etc. Here, the analysis takes as a core 'fact' that biologists and philosophers are not always referring to the same thing when they describe or theorize organism. One possible consequence is that drawn by Machery, with reference to the concept of life; another consequence, less eliminativist, is that suggested by philosophers of biology but also biologists, that we should allow for more elasticity in our sense of what 'organism' can refer to, from slime molds to primates, but also from coral reefs to symbionts, there are 'degrees of organismality' (Bouchard, 2009, 2013; Queller and Strassman, 2009). That is, instead of an either/or sense in which an organism, a superorganism or a collection either is an individual or is not, there is a sense, e.g. an evolutionary sense, in which collections can "become individuals" (Bouchard and Huneman, 2013, p. 3). The latter sense allows of a more elastic kind of reference, matching up with what I have called the productivity of the organism concept: following a suggestion of Evelyn Fox Keller's (here, regarding the concept of gene), "even the absence of a clear and univocal meaning of the very concept of the gene-that is, of the basic explanatory unit - can be a positive resource for drawing different experimental systems and different research programs into a coherent scientific agenda" (Keller, 2003, p. 120).

The organism as go-between, rather than as a concept with a strict reference, is desubstantialized, at least in the sense that it is a non-essentialist, non-foundational concept. A substantialized concept of organism can either be based on empirical criteria (self-organization, self-regulation, internal cohesion, etc., with various problem cases arising such as reproductive potential or fissibility) or on irreducible metaphysical criteria of individuality. Sometimes the latter even take on a hypertrophied, dualist form in which the living organism and its 'potential', its activity, are opposed to mechanistic explanations and indeed to a mechanistic worldpicture. To cite one example among many, this is the rather fearful, emotional motivation of anti-reductionist 'biophilosophers' like Raymond Ruyer, who was prominent in post-war French thought. Ruyer, in this quite close to a tradition of primarily German Romantic

\footnotetext{
${ }^{4}$ I have offered some criticisms of my own against 'criteria-based' theories of organism, which he calls 'definitional', in Wolfe, forthcoming 2014b.
} 
biophilosophy, defends an explicitly anti-naturalist concept of organicism: he insists on the nonspatiality of the organism, its sheer potentiality (Ruyer, 1946, pp. 8, 14, 27, 58, 94), over and against the reductionist fate he fears modern science brings with it, of a universe composed of inanimate matter, with shocks and displacements explainable exhaustively by the laws of mechanics. Against this world, in which the organism is no longer anything more than a machine, Ruyer warns: "If you are shocked by what amounts to a generalized 'theory of organism', ... you had better see clearly that the choice is between this theory and that of a 'generalized molecule'" (Ruyer, 1952, p. 166). What I have called the normative, valuative but also the polemical dimension of the concept of organism is prominently on display here.

So on the one hand, the organism is an oppositional concept, often with polemical and/or affective value: it serves to assert one 'realm', one ontological or scientific domain over and against another (the physical universe as a whole; mechanism; inanimate matter; forms of life below the threshold of consciousness - for defenders of the concept of organism, however diverse they may be, viz. Walter Elsasser and Hans Jonas share neither a metaphysical nor a scientific outlook, do not tend to be interested in 'microorganisms' or forms of life such as the amoeba or the slime mold (Dictyostelium). Von Uexküll's tick would be something of a counterexample, for it is an empirical case meant to justify a holist theory of organism, in which each organism lives in a dynamically constituted Umwelt which is unique to that organism: ticks perceive only that which is relevant to them, just as dogs and seahorses do. Organisms on this view are "closed unit[s]" (von Uexküll, 2010, p. 42), as are their Umwelten: "Each environment forms a self-enclosed unit, which is governed in all its parts by its meaning for the subject" ( $p$. 144). Von Uexküll's further holist emphasis is that we should understand the tick, like every other organism, as a "subject" rather than as a "machine": "The biologist . . . takes into account that each and every living thing is a subject that lives in its own world, of which it is the center. It cannot, therefore, be compared to a machine" (p. 45). Von Uexküll's tick, like Kurt Goldstein's brain-damaged patients (Noppeney, 2001), is not a model organism but rather a paradigm case of organism as an irreducible, individual substance. ${ }^{5}$

But on the other hand, organism is a hybrid concept, from its early argumentative usage onwards (i.e., as a term of argument, not a casual or obscure term), through its trials and tribulations as a key term of biology or a term to be rejected. Namely, one author will use the organism concept to give metaphysical grounding to an empirical claim (for example, Kant insists that in organisms the "idea of a whole" is present as a "principle of knowledge" [Kant, $1790, \S 65]$, which is not an empirical feature but a "condition of our understanding of organs

\footnotetext{
${ }^{5}$ Goldstein credits von Uexküll explicitly for this concept. In addition, it is not irrelevant that von Uexküll was one of the founders of theoretical biology as a discipline, authoring what is probably the first work to bear that title (von Uexküll, 1926).
} 
and traits as parts of a single organism" [Huneman 2014; Kant, 1790, § 77]) ${ }^{6}$, while another author will insist that it is purely empirical - not to mention further instances of hybridity between the biological and the social (e.g. Lamarck as discussed in Gissis, 2009), the biological and the neuropsychological, and so on.

The tension between the metaphysical and the empirical is present in the earliest 'conceptual' usage of the term 'organism', in the debate between Gottfried Wilhelm Leibniz and Georg-Ernest Stahl in the early years of the eighteenth century. This was not its very earliest usage, which seems to have been in the fourth edition of John Evelyn's Sylva, 1706, first published in 1664 (Cheung, 2006, p. 322), but rather its usage as a technical term with specific conceptual content. One must distinguish this specific 'conceptual' usage from other early occurrences where the meaning is not yet stabilized or clear, as late as Diderot and D'Alembert's Encyclopédie, where 'organism' is used synonymously with 'mechanism'. ${ }^{7}$ The Leibniz-Stahl debate was based on Leibniz's reply to Stahl's Theoria medica vera (1707), and their ensuing controversy, the texts of which were published under the title Animadversiones circa Assertiones aliquas Theoriae Medicae Verae clarii Stahlii, cum ejusdem Leibnitii ad Stahlianas observationes responsionibus or, more unkindly, Negotium otiosum (Huneman and Rey, 2007, Duchesneau, 2014). ${ }^{8}$ In the next sections (3 and 4) I address some particular historical cases, from the Leibniz-Stahl debate on the difference between organisms and mechanisms to eighteenth-century Montpellier vitalist conceptions of the 'animal economy' (an organism concept) and Claude Bernard's concept of organic individuality, in order to further illustrate the fruitfulness of this hybrid, non-essential, and perpetually nomadic concept of organism. I then contrast this concept with a stronger form of organicism (section 5 ) before concluding.

3.

While Stahl insists on the ontological uniqueness of organism, Leibniz, for whom "everything in nature is to be explained mechanically" (Leibniz, first essay on Stahl, 1708, cited from the bilingual edition in Carvallo, 2004, p. 73) and who often explains bodies in terms of

\footnotetext{
${ }^{6}$ But Kant also can emphasize empirical features such as self-organization: "organized beings are beings that selforganize" (Kant, 1987, § 65).

7 In the Encyclopédie articles "Fibre" and "Nutrition" (VI, p. 670; XI, p. 288) the terms "méchanisme" and organisme" are used interchangeably, e.g. "the mechanism or organism of nutrition." There is no article "Organism(e)" in the Encyclopédie, contrary to what is asserted in Ibrahim, 1999, p. 652, an otherwise very useful study (she refers to Enc. XI, p. 360, which is indeed the beginning of the important "Economie animale" article).

${ }^{8}$ Leibniz wrote some remarks on the Theoria medica vera in 1709 , and had them sent to Stahl. Stahl responded some months later, but Leibniz was unconvinced, and reiterated his critique in the 1711 Replicatio ad Stahl observationes, to which Stahl replied at even greater length.
} 
size, shape and motion, discusses organisms as particular, but special cases of a mechanical universe: he calls them "machines of nature," which he defines as machines in their most minute parts ("moindres parties"), contrary to machines created by human artifice (Leibniz, 1978, IV, p. 482); machines down to infinity, also in the sense that bodies contain seeds which can never be destroyed (ibid., p. 475). The term 'organism' is often presented as first appearing in his New System of Nature, published in 1695 in the Journal des savants, but Leibniz uses it in Latin and German as well (and in a short 1686 text entitled "Du rapport général de toutes choses," he speaks of "all the parts of matter" as being "full of organism" (pleines d'organisme): \# 311 in Leibniz, 1999, p. 1614). But Leibniz primarily uses the term "machines of nature." In the Monadology $(\S 64)$ he presents this terminology as a definition of living bodies. The Leibnizian 'organism', in this sense, is a complex kind of machine: "The organism of a living being (organismus viventium) is nothing other than a divine mechanism which is more subtle than an ordinary mechanism in the infinity of its subtlety" (Leibniz, 1961, 16, § 13; Leibniz, 1978, I, p. 15). Leibniz denies any kind of extra-causal influence on bodies of a vital principle that would be separate from bodies as a whole, which is precisely what Stahl's anima is: soul as the motive force or controller in the body.

To be clear, these are not just competing empirical explanations of soul:body or whole:parts interaction, both of which would amount to 'definitions of organism'; they are ontologically different. Better put, Leibniz refrains from fully ontologizing the concept of organism: "'Organism' and 'mechanism' in Stahl designate two regions of being. Leibniz, on his part, hardly says 'organism', preferring terms such as 'organized being', 'organized body' or 'organic machine', because organization is a univocal concept, equally applicable to inanimate or artificial beings, and to living beings" (Huneman and Rey, 2007, p. 223). Granted, both concepts are opposed to that of 'machine', but the mainstream sense of 'organized body' or 'animal economy' (Wolfe and Terada, 2008) differs from that of 'machine' incrementally rather than categorically, whereas for Stahl, organism is something unique within Nature as a whole. Leibniz and Stahl in their debate both contribute to our conception of organism, including by introducing the term in a recognizable technical sense in which it is opposed (although how exactly is precisely something they disagree on) to the idea of a machine, as a special kind of unity, composition or 'whole'. ${ }^{9}$ Conceptually speaking, the Leibnizian idea that an organism differs from a machine in terms of degrees of composition, incrementally, is much closer to the current idea of 'degrees of organismality' (Queller and Strassman, 2009), in the sense that ontological specificity is presented as being on a gradation than a matter of irreducible uniqueness.

\footnotetext{
${ }^{9}$ For an excellent general presentation of the 'machines of nature' concept in Leibniz, see Fichant, 2003 ; for an analysis of Leibniz with a philosophy of biology focus, different from the present one as it focuses on the 'units of selection' debate, see Nachtomy, Shavit and Smith, 2002.
} 
It is not too big a step from this incremental vision of organism as a particular, complex arrangement of matter, which we also find in eighteenth-century vitalism, as I discuss below, to the project of a science specific to such entities, namely biology (on the shifts involved, both terminological, instrumental-material and ontological, see Caron, 1988, McLaughlin, 2002, Wolfe, 2011). The term 'biology' is generally held to have appeared in the 1790s with Lamarck and Treviranus, which would then imply roughly a century's interval between the first technical usage of 'organism' and that of 'biology', from the early 1700 s to the late 1790s. But in fact, recent work has shown that 'biology' appears as early as 1766 (McLaughlin, 2002), with then a terminological fluctuation for some decades (terms such as 'zoonomy' being other candidates) - which itself reveals a desire to account for a reality, whether we call it a practical and instrumental reality, or an ontological state of affairs.

This runs directly counter to the common view according to which the constitution of biology as a science had no relation to questions such as 'what is Life?' or ontological concerns with the specificity of life (as in Keller, 2003, pp. 15-16). The view I am suggesting, that a concern with the nature of the reality of organisms plays a role in the constitution of biology (without this having to be a commitment to a strongly ontological view of organisms) is apparent, for instance, when Caspar Friedrich Wolff seeks to redefine embryology, precisely in this period, he states that one of the main goals of his "theory of generation" is not just to defend epigenesis as an account of the formation of the embryo, but also more broadly, to define a science of the causes and effects specific to the formation of organisms ("organized bodies," Wolff, 1764/1966, p. 36f.). What is specific to the embryo and more generally the organism is the presence of a force Wolff calls vis essentialis.

The oppositional motivation in these classic modern concepts of organism, from Stahl to Wolff and beyond, is to produce a model of life which is non-mechanical, or not fully mechanical. One can describe them as 'holistic', to use an early-twentieth century term although curiously, holism, which is associated with systems theory, is not a doctrine specifically about living beings, contrary to a widespread misconception (Wolfe, 2010). For example, the founder of systems biology, Ludwig von Bertalanffy, invokes holism as a total systemic standpoint with no reference to any special status of living entities, even though in the same text he also claims that this standpoint sheds particular light on embryology and how organisms are not mere machines, notably due to their teleological and 'historical' character (von Bertalanffy, 1934, pp. 9, 33, 52).

For the holist, the difference between an organism - a flesh-and-blood creature which falls ill, resists the challenges of its environment and conversely, assimilates the substances that will enable it to survive - and a machine, is a difference between two types of 'whole' (as is often mentioned, 'holism' comes from the Greek holos, 'whole'). If a living whole is greater than 
the sum of its parts, or conversely, in Aristotle's example, if a hand cut off from the body is no longer a hand, ${ }^{10}$ in what Deborah Modrak has described as a normative usage of the natural function of an organ (Modrak, 1996, p. 158), by contrast, the inert or passive whole of a machine is, for Leibniz as for a variety of thinkers he influences, a mere "aggregate" of parts (Wolfe, 2006). Holism often, as in the early twentieth-century German Ganzheitsbetrachtung, conceives of its object in opposition to 'mere mechanism', atomism, reduction, and other instances of explanation in terms of decomposition into parts. But the historical reality yields a different picture, in which 'machine' and 'organism' are not independent of one another, such that there are mechanist features (if admittedly of a rather pluralistic sort) in most definitions of organism. Again, this illustrates both the historical diversity of concepts and contexts of organism, and the sense that its ontology would have to be one of degrees, gradations and shifts.

4.

Machine and organism are in interplay here, with the concept of organism being articulated, partly (in Leibniz) or wholly (in Stahl), in contradistinction to the concept of machine, with at least two different dimensions involved. One is the type of individuality that is being argued for: what kind of individual is the organism? Indeed, all or most theories of organism attempt to justify the existence of a particular kind of individuality. For Claude Bernard, "the physiologist and the physician must never forget that the living being comprises an organism and an individuality ... If we decompose the living organism into its various parts, it is only for the sake of experimental analysis, not for them to be understood separately" (Bernard, 1865/1984, II, ii, § 1, p. 137). But the other dimension is a kind of hybridity in which neither machine nor organism are 'pure' or entirely separate from one another (Canguilhem, 2008). That is, historically, the evidence is in favor of such a status of the organism concept. Various examples can be given; those I give below are meant to illustrate the interpenetration of machine and organism concepts, or of mechanical and organismic conceptions in an interaction.

In early modern French, words like 'body' and 'machine' were often defined interdependently, e.g. in the Dictionnaire de l'Académie, which defines 'machine' in 1694 as "a set of parts or organs which form a whole, living or not, and produce determinate effects without transmitting a force externally; organism, body" (Cayrou, 1948, s.v. “Machine," p. 530).

\footnotetext{
${ }^{10}$ Metaphysics Z 11, 1036b32. The idea is that the material structure of a part per se matters less than 'where' it is: "blood will not be blood, nor flesh flesh, in any and every state" (Generation of Animals I.18, 722b34); a hand can only be understood as a hand inasmuch as it belongs to an ensouled body, i.e., matter animated by a form.
} 
By the nineteenth century the situation is different, with the Encyclopédie méthodique explaining that one should no longer use the expression "human machine" ... but that "animal economy" or "organism" are suitable substitutes:

It is preferable to use the synonymous expressions 'living economy', 'vital economy', 'animal economy', 'organism', 'organic mass', 'the entire economy of the human body'. The term 'machine' seems to refer to a system of causes and effects which belongs wholly to the mechanistic theory ("Machine," Vicq d'Azyr, ed., 1808, p. 310).

Yet 'animal economy' and 'organism' are not being defined here in some kind of deep opposition to 'machine'. Similarly, mechanist concepts of Life and their purportedly opposite organicist rivals exist in a historical, conceptual, and instrumental reality which is much more hybrid and 'dialectical' than their usual, oppositional presentation, in the simple sense that they do not function as logical contraries, but as progressive modifications and displacements in the project of understanding one and the same object, the living organism (Wolfe, forthcoming 2014a). In recent discussions of 'mechanism', the emphasis is indeed on the role 'mechanisms' play in biological explanation; but even in classical forms of mechanism (Cartesian, corpuscular, or Newtonian-inflected as in Boerhaave) the goal is always to do justice to the target of the explanation: the functional properties of living systems. The same applies in a case we have been conditioned to think of as an opposite: the first self-described form of vitalism, namely, the school of Montpellier vitalists, that is, a group of physicians and professors of medicine associated with the Montpellier Medical Faculty, especially in the second half of the eighteenth century. The best-known figures here were Paul-Joseph Barthez and Théophile de Bordeu, to whom we should add less famous, but equally significant individuals such as Henri Fouquet and Jean-Joseph Ménuret de Chambaud (Wolfe and Terada, 2008).

For present purposes, what is significant about the vitalist approach to the organism (which it mainly refers to as "animal economy") is that it is articulated, not by postulating the existence of an invisible vital force, but in structural terms, that is, by describing the functional organization of a system of living organs as a kind of extra-complex mechanism with purposive properties. In a programmatic article in Diderot and D'Alembert's Encyclopédie entitled, precisely, "Economie Animale," Ménuret presents those who explain the functioning of the living body by the presence of an immaterial soul (i.e., "animists") and those who reduce the body to a mere machine, as equally mistaken: "They did not even pay attention to the organic structure of the human body which is the source of its main properties" (Ménuret, 1765, p. 364b). But this organic-structural view is not anti-mechanistic; rather, it understands the living body in enhanced mechanistic terms: 
everything leads us to believe that the human body is like the other machines which art can assemble, disassemble, and witness in their tiniest springs; it is a fact known to any artist, that in even the most complex machines, the entire movement rests and bears on one particular piece from which the movement began, and from which it spreads to the rest of the machine, producing various particular effects in each particular spring. It is only on the condition of such a spring in man that we can come to properly know and determine the manner of acting of the general causes of life, health, sickness and death (Ménuret de Chambaud, 1765, p. 362b).

Claude Bernard also articulates a twofold vision in which mechanistic and organismic levels are intertwined, describing the organism as an "admirable machine" but also a "living machine" (Bernard 1865, II, ch. i, §§ iii, vii), with a greater emphasis on self-organization: "[W] hat distinguishes a living machine is not the nature of its physico-chemical properties, complex as they may be, but rather the creation of the machine which develops under our eyes in conditions proper to itself and according to a definite idea which expresses the living being's nature and the very essence of life" (ibid., ch. ii, § 1).

5.

In this back and forth movement of definitions between living body and machine, including multiple degrees and gradations of both, where the mechanical model is 'frontloaded' with increasingly chemical and biological features, and the models of the living body incorporate a variety of mechanistic and structural features, it is hard to distinguish clearly between the metaphysical level and what we would today call the scientific level. This is also the case when the model takes an existing structure such as the interrelation of organs in the living body, and then seeks to describe this interrelation in higher-level terms, as e.g. in the Montpellier vitalist way of conceptualizing the components (organs) as so many "little lives," joined together into a single individual 'Life' - often expressed in the metaphor or analogy that the organism or 'animal economy' is like a "beeswarm," each component of which is already a 'life' of its own (see Wolfe and Terada 2008, § 3, and the introduction to Bouchard and Huneman 2013). This combination of levels again illustrates how the concept of organism is a porte-manteau concept, on which one hangs various, rather disparate research programs in physiology, biomedicine and philosophy. Even if the elaboration of an organism concept can be summed up, as Canguilhem does, as "the search, by naturalists, physicians and philosophers, for replacements or semantic equivalents for the soul, which could account for the increasingly well-established fact of the functional unity of a system of integrated parts" (Canguilhem, 1989, p. 551), this does not mean it was a straightforward articulation of a neutral, 'scientific' 
concept. Notably, because it is also a polemical concept, and often one which belongs to a revisionary program, sometimes known as 'organicism'.

Organicism, in philosophy and in theoretical biology (itself extending work done earlier in embryology, physiology, biochemistry and more recently, ecology and evolutionary biology), asserts the existence of an irreducible reality of organisms. In the latter discipline, figures such as Walter Elsasser in the 1960s, Robert Rosen in the 1980s, and - with a different, often more metaphysically oriented program - Francisco Varela between the 1970s and his death in 2001 sought to formulate 'laws' or systemic regularities that would define the organism, often using models derived from physics or dynamic systems theory. In the early twentieth century, the organicism of Hans Driesch (often termed 'neovitalism') lacked such conceptual tools, and founded itself on the challenging experimental 'evidence' of the equipotentiality of sea urchin eggs. As is well known, Driesch gradually left the domain of biological science for that of metaphysics, theorizing the 'entelechies' that, on his view, explain these properties (Kull, 2013).

In fact, as I indicated above with the case of Montpellier vitalism, there are both historical and conceptual reasons to take such strong (ontological) claims with a grain of salt. The type of organism concept which emerges with the montpelliérains is explicitly hostile to any appeal to mysterious, non-experimentally (or experientially) based entities, not least because it comes out of a medical context, implying a focus on living rather than dead bodies, and on the living body as a 'total' living system rather than as a parcel of decomposable matter. As distinguished from 'strong organicism', we could call this concept 'weak organicism'. For instance, the erstwhile Dean of the Montpellier Medical Faculty, Paul-Joseph Barthez, who had initially spoken of a vital principle in his 1778 Nouveaux éléments de la science de l'homme, added a chapter to this work entitled "Skeptical considerations on the nature of the vital principle" in the revised edition, stating "I am as indifferent as can be to ontology considered as the science of entities" (Barthez, 1806, p. 96, n. 17).

Nevertheless, weak organicism is still organicism: notably, it will criticize the "mechanists" (in the restrictive sense of those who explain the functioning of the body as if it were a machine), not in the name of irreducible holism, but for failing to acknowledge or do justice to "the organic structure of the human body, which is the source of its main properties" (Ménuret 1765, 364b), by geometrizing it. Bordeu speaks of the mechanical analogies popular during the previous hundred years (e.g. in iatromechanism) as "the playthings of our fathers":

Spare us, once and for all, all these tiny fibres, pressures, globules, thick substances, sharp angles, lymph, hammers and all the rest of the equipment from mechanical workshops with which [earlier doctors] filled the living body they were the playthings of our fathers (Bordeu, 1764, in Bordeu, 1818, II, p. 670). 
We can read this as just an ironic taking of distance with the obsession in early modern science (especially in the mid-to late seventeenth century, the time of Descartes, Borelli but also of the Scottish 'medical Newtonians' like Pitcairne, whose works read much like Bordeu's description above), or as a stronger, frontal opposition, invoking a kind of 'essence' of the organism which these mechanistic metaphors cannot grasp. This is not the place to go into detail as to how and why I think the eighteenth-century vitalist response to mechanism is more the former than the latter, i.e., more a 'desubstantialized' argument and rather less a 'substantial' ontological commitment (for more details see Wolfe and Terada 2008). For present purposes, I claim that this supports my distinction between a less essentialist but also less 'pure', less monolithic concept of organism (the hybrid concept) and a stronger concept.

Strong organicism, which asserts the intrinsic, objective reality of the organism, is diametrically opposed to a Kantian, projective vision, which is not an appeal to an intrinsic reality but rather to epistemic features of how we construct the world into intelligible forms. This opposition between a strong ontological commitment to the uniqueness of organisms and an epistemological theory (which in its own way also insists on their uniqueness), can also be nuanced, bearing in mind cases such as Kurt Goldstein's constructivist approach in his work on the 'organismic' properties of both our minds and bodies, which emphasizes the inherently constructed character of organisms, but also that this constructed character is part of their specific dynamic activity, of worldmaking (Goldstein, 1934/1995, Ferrario and Corsi, 2013). These approaches, like the standpoint of the Montpellier vitalists discussed above, are nonsubstantialist, but in addition, they are specifically constructivist, i.e., organism here is primarily emphasized as a meaningful construct, a part of Nature which has been rendered intelligible (or meaningful). In Daniel Dennett's evocative example, if I am being pursued by a tiger in the rain forest, I will be better off treating it as an intentional agent (an organism, in the present context) rather than as a mere heap of atoms or molecules, as this will enable me to predict its behavior better and increase my chances of survival (Dennett, 1987); neither Kant nor Goldstein give the idea that our perception is irreducibly organicist, such a Darwinian coloration. ${ }^{11}$ One of the original organicists in the twentieth-century biological sense, Joseph Needham, also took this position but from a more 'total systemic' standpoint, according to which organicism is a stance rather than a theory. For Needham, "all things are organisms and all things are atomic systems also. You choose your standpoint," or in more detail,

Both [mechanism and vitalism] are co-extensive with experience, but one is appropriate to science, the other to philosophy; there is no further need for any

\footnotetext{
${ }^{11}$ It can also be argued, as Wiggins does, that this capacity of organisms to 'construct the(ir) world' meaningfully has irreducible nomological properties, but that would, again, be a metaphysical claim concerning the nature of certain types of substance, rather than an attempt at the 'historical epistemology' of the organism as go-between, as proposed here. (I thank Adam Ferner for helping me to see this with regard to Wiggins.)
} 
fighting to go on in biology between those to whom the concept of organism is the more profound and to those who feel the same about that of mechanism, for all things are organisms and all things are atomic systems also. You choose your standpoint, and you see what is to be seen from that standpoint (Needham, 1930, pp. 84-86).

\section{Conclusion}

Rather than seeking to articulate an organism concept on a strictly empirical basis (including in the 'organizational' sense developed in Wolfe, 2010), I have tried to do so by insisting on what I have called its hybridity and its status as an 'ontological go-between'. Usually, the concept of hybridity refers to a condition or state (notice how the potential dynamism within such a condition will then most likely fade into the background) of impurity, whereby there is a co-existence or simultaneous presence within a particular concept, or theory, or practice, of various identifiable elements (themselves understood as rather peculiarly self-contained), categorizable as 'naturally' falling under pre-established, distinct frameworks (such as the elements of mechanism within Montpellier vitalism, or of organicism in Cartesian accounts of health). ${ }^{12}$ But here, hybridity simply means that the concept of organism is never pure or analytically unresolvable. It is always partly constructed or modified or borrowed from elsewhere (including when its functions normatively as legitimization), sometimes invoked as a simple natural 'case' which buttresses a metaphysics, or on the contrary as a value-laden entity which stands against a 'merely' physical world (as is also the case, partly, in Kurt Goldstein's theory of organism): always in a process of borrowing.

If the organism is a hybrid but also a go-between concept - not just a 'coat of many colors' or a perpetual patchwork, but a robust concept in its way of articulating connections that do not always "adhere to the usual stipulations of empirical warrant" (Peterson, 2012) - isn't it still just a construct, since we are not dealing with absolute, isolable entities or states of being? I have suggested at least two reasons why not.

One is that there are definitely more ways to study the materiality of worms and wombats, but also slime molds, coral reefs and giant fungi, than just as metaphors, given that "within an overall field of science, there may be variation regarding the epistemic goal(s) pursued by a term's use" (Brigandt, 2010, p. 23). That is, the individuation of a concept - here, organism - can be based on different properties, including its reference and its 'epistemic goal' (p. 25). The epistemic goal here is a necessary component of any philosophical framework that wants to explain

\footnotetext{
${ }^{12}$ I thank Claudia Alexandra Manta for this point.
} 
conceptual change. A merely referential criterion won't be sufficient, (a) because it runs the risk of confusing the empirical and the metaphysical, in my terms; (b) because Aristotle's, Jonas's or Ruyer's referential criteria for organism might not match up with, e.g., Godfrey-Smith's 'squibrio' described below. The hybridity feature in my analysis implies that the variable, instrumentalist dimension is not 'merely instrumental' as in the instrumentalism-realism opposition. Nor is it just a matter of the fruitfulness of 'travelling concepts' (Bal), or the diversity of possible standpoints à la Needham, but rather a hybrid reality, as I discuss below.

Another is that these are individual substances, even if their boundaries are not always clear or matching up to our common intuitions of what an individual would be (Bouchard and Huneman, eds., 2013); to take one example, "the omnipresence of symbiosis should be seen as undermining the project of dividing living systems unequivocally into unique organisms" (Dupré, 2012, p. 8). There are also cases in which symbiotic individuals are not what GodfreySmith recently called 'Darwinian individuals', as they do not form parent-offspring lineages, such as the symbiosis discussed by Godfrey-Smith between the Hawaiian bobtail squid (Euprymna scolopes) and the bacteria Vibrio fischeri, which grow into colonies in specialized 'crypts' inside the squid, which form part of the squid's 'light organ'; he suggests calling the squid-Vibrio combination a 'squibrio'. ${ }^{13}$ Of course, I am not seeking to reintroduce an 'Aristotelian' concept of organisms as paradigmatic individuals through the back door. After all, it would seem difficult for a hybrid concept to also be a paradigmatic individual. This is why I have insisted on hybridity as matching up with a weakly ontological concept, in the sense that in-between or non-traditional cases such as termite mounds with their homeostatic properties, bacteria, coral reefs and 'squibrios' challenge our monolithic intuitions about the individuality of organisms yet at the same time emphasize the materiality of the concept, something not to be dispensed with or reduced to a merely instrumental status. Degrees of organismality are real!

While some might take this talk of 'degrees', of shifts, of borrowings and displacements between the empirical and the metaphysical, or between different scientific areas, as an indicator of the emptiness of the organism concept, of its outdated character (in favor of a "nothing but atoms or molecules" view, sensu Hull positively and Ruyer negatively, or of a provisional view as in the standard instrumentalist sense), and others might balk at any reference to ontology and opt for a strictly epistemological view (Keller) or an insistence that we are dealing with metaphors and nothing more, my suggestion is that the hybridity of the

\footnotetext{
13 "This light organ lights up in a way that provides camouflage from predators watching from below, as it prevents the squid from casting a shadow. This shadow would be cast by moonlight - the squid hunts at night. At the dawn of each day, most of the bacteria are expelled, and the colony regrows from the remainder while the squid hides on the sea floor. It can be argued that the squid-Vibrio combination is the organism (perhaps a 'squibrio')" (Godfrey-Smith, 2013, p. 29).
} 
organism concept - the way that mechanistic concepts of body (e.g. Cartesian physiology) are not without embodied, organismic properties, just as vitalistic concepts of, e.g. the animal economy are not without mechanistic specifiable features, along with later examples including Claude Bernard's 'living machine', so that the concept is never pure or analytically unresolvable - also presupposes a degree of reality, which is built on the historical and scientific variety of organism models and definitions: a kind of meta-instrumentalism. What I have described as hybridity and go-betweenness at the conceptual level can of course also be studied in the materiality of scientific apparatuses, as Hans-Jörg Rheinberger has done influentially: "Conjunctures, hybridizations, and bifurcations basically describe types of shifts, linkages, and descents through which the dynamics of reorientation, fusion, and proliferation of particular experimental systems is made possible" (Rheinberger, 1997b, p. 250). Rheinberger additionally emphasizes a cognitive, constructed level of the effectivity of scientific practices: his experimental systems do not just inhabit a world of 'things' but also, what he calls "graphematic spaces," capable of "differential reproduction" (Rheinberger 1998, p. 287); indeed he also speaks of "epistemic practices" as being "hybrids" that can be classified as either theoretical or practical (ibid., p. 286).

The reality of the organism concept in this sense is partly correlated with the emergence of biology as a science, even if biologists and philosophers have observed more recently (Jacob, 1970; Keller, 2003; Machery, 2012) that there is no need for biology to have 'life' or any other sharply defined concept at its center; if, that is, "Biology has developed as a discipline without having anything terribly precise to say about exactly what its domain of inquiry is," so that "perhaps 'alive' is not a crisply delimited category in nature" (Sober, 2003, p. 318). What we have, then, is a weakly ontological organism concept, as some biologists call for: not as an umbrella concept to organize all of some kind of reconceived 'organismic' biology, nor as a reactive concept against 'mechanistic' or 'reductionist' science, but simply as a way of doing justice to certain kinds of systems, as Scott Turner has insisted, among others. This is similar to Gilbert and Sarkar's analysis of various trends in recent biology that share a common opposition to genocentrism: they aim to reconstruct an approach to specific forms of organization - not the naïve metaphysics of arrangements of matter plus an immaterial Bildungskraft, nisus formativus or an otherwise specified 'life-force' (Gilbert and Sarkar, 2000). Thereby, despite having frequently been pronounced 'caduc', irrelevant, reduced to molecules or genes, the concept of organism retains a productivity - nomadic but thereby real. Yet this perpetuation is far removed from any 'metaphysics of organism', or old-fashioned organismic biology.

Rather than an essence of organism or a substantialist theory (selfhood, subjectivity, personhood, continuity, etc.), it is characterized by its go-betweenness or nomadism, itself reminiscent of notions such as "boundary concepts" or "trading zones"; to borrow a term from Rheinberger, who applied it to the admittedly deliberate constructs he names "epistemic things," 
the organism is a "joker" (Rheinberger, 1997b, p. 246), not in the sense that it is humorous, but rather that it is like the card which can play different roles within a given card game. If certain conceptual constructs are jokers for the world of practice (e.g., when the Kantian whole:parts conception of organism is used in early nineteenth-century German developmental biology: Huneman, 2014), conversely, certain material-conceptual constructs are also jokers for the world of biological theory (as in the way Hans Driesch turns his experimentally founded work on the regenerative potential of sea urchin embryos into a metaphysics of 'entelechies'; Kull, 2013, or Hans Jonas' transformation of the biological 'fact' of homeostasis into a basis for a revisionary, anti-Cartesian metaphysics of life). As I've shown in some select cases (others might focus more on Kant or systems biology (Toepfer, 2013)), the historian and the philosopher of biology might benefit from paying some attention to the organism concept, whether out of interest in individuality and organization, in the pertinence of hybrid concepts in the history and philosophy of science, or more generally in the emergence of the science of biology.

\section{Acknowledgments}

Thanks to Claudia Alexandra Manta, Adam Ferner, and Anya Plutynski for their suggestions and to the anonymous reviewers for their comments.

\section{References}

Allen, G.E. (2005). Mechanism, vitalism and organicism in late nineteenth and twentiethcentury biology: the importance of historical context. Studies in History and Philosophy of Biological and Biomedical Sciences, 36, 261-283

Bal, M. (2002). Travelling Concepts in the Humanities: A Rough Guide. Toronto: University of Toronto Press.

Barthez, P.-J. (1806). Nouveaux éléments de la science de l'homme. Paris: Goujon \& Brunot. Bechtel, W. (2007). Biological mechanisms: Organized to maintain autonomy. In F. Boogerd et al. (Eds.), Systems Biology: Philosophical Foundations (pp. 269-302). New York: Elsevier. Bernard, C. (1865). Introduction à l'étude de la médecine expérimentale. Paris: J.B. Baillière \& Fils.

Bernard, C. (1879). Leçons sur les phénomènes de la vie communs aux animaux et aux végétaux, tome II. Paris: G. Baillière. 
Bertalanffy, L. von. (1934). Modern Theories of Development: An Introduction to Theoretical Biology, trans. J. H. Woodger. Oxford: Oxford University Press

Bordeu, T. de. (1764). Recherches sur quelques points d'histoire de la médecine. Paris: Cailleau. Bordeu, T. de. (1818). CEuvres complètes, 2 vols. Paris: Caille et Ravier.

Bouchard, F. (2009). Understanding colonial traits using symbiosis research and ecosystem ecology. Biological Theory, 4(3), 240-246.

Bouchard, F. (2013). What Is a Symbiotic Superindividual and How Do You Measure Its Fitness. In F. Bouchard, P. Huneman (Eds.) From Groups to Individuals: Evolution and Emerging Individuality (pp. 243-264). Cambridge, MA: MIT Press, Vienna Series in Theoretical Biology. Bouchard, F. and Huneman, P. (Eds.) (2013). From Groups to Individuals: Evolution and Emerging Individuality. Cambridge, MA: MIT Press, Vienna Series in Theoretical Biology.

Brigandt, I. (2010). The Epistemic Goal of a Concept: Accounting for the Rationality of Semantic Change and Variation. Synthese, 177 (1), 19-40.

Brigandt, I. (2012). The Dynamics of Scientific Concepts: The Relevance of Epistemic Aims and Values. In U. Feest, F. Steinle (Eds.), Scientific Concepts and Investigative Practice (pp. 75-103). Berlin: De Gruyter.

Buffon, G. -L. L. de (1753). Histoire naturelle, générale et particulière, IV. Paris: Imprimerie Royale.

Canguilhem, G. (1989). Vie. Encyclopedia Universalis, 23, 546-553.

Canguilhem, G. (2002). Le problème des régulations dans l'organisme et la société. In Canguilhem, Écrits sur la médecine (pp. 101-125). Paris: Éditions du Seuil.

Canguilhem, G. (2008). Machine and Organism (1946-1947). In Canguilhem, Knowledge of Life. Eds. P. Marrati \& T. Meyers; trans. S. Geroulanos \& D. Ginsburg (pp. 75-97). New York: Fordham University Press.

Caron, J. (1988). 'Biology' in the Life Sciences: A Historiographical Contribution. History of Science, 26, 223-268.

Carvallo S. (2004) La controverse entre Stahl et Leibniz sur la vie, l'organisme et le mixte. Paris: Vrin.

Cayrou, G. (1948). Le français classique. Lexique de la langue du dix-septième siècle. Paris: Didier.

Cheung, T. (2006). From the organism of a body to the body of an organism: occurrence and meaning of the word 'organism' from the seventeenth to the nineteenth centuries. British Journal for the History of Science, 39(3), 319-339.

Coleman, W. (1977). Biology in the Nineteenth Century: Problems of Form, Function and Transformation. Cambridge: Cambridge University Press. 
Dawkins, R. (1976). The Selfish Gene. Oxford: Oxford University Press.

Dennett, D. (1987). Eliminate the middletoad! Comment on J.-P. Ewert's 'Neuroethology of releasing mechanisms: Prey-catching in toads'. Behavioral and Brain Sciences, 10(3), 372-373 Duchesneau, F. (2014). 'Organism' in the Leibniz-Stahl Controversy. In O. Nachtomy and J.E. H. Smith (Eds.), The Life Sciences in Early Modern Philosophy(pp. 98-114). Oxford: Oxford University Press.

Di Paolo, E. (2009). Extended Life. Topoi, 28, 9-21

Dupré, J. (2012). Processes of Life: Essays in the Philosophy of Biology. Oxford: Oxford University Press.

Ferrario, C.E. and Corsi, C.E. (2013). Vitalism and Teleology in Kurt Goldstein's Organismic Approach. In S. Normandin and C.T. Wolfe (Eds.), Vitalism and the Scientific Image, 1800-2010 (pp. 205-241). Dordrecht: Springer.

Fichant, M. (2003). Leibniz et les machines de la nature. Studia leibnitiana, 35, 1-26.

Galison, P. (1999). Trading Zone: Coordinating Action and Belief. In M. Biagioli (Ed.), The Science Studies Reader (pp. 137-160). London: Routledge.

Gilbert, S., Sarkar, S. (2000). Embracing Complexity: Organicism for the $21^{\text {st }}$ Century. Developmental Dynamics, 219, 1-9.

Gissis, S. (2009). Interactions between Social and Biological Thinking: The Case of Lamarck. Perspectives on Science, 17(3), 237-306.

Godfrey-Smith, P. (2013). Darwinian Individuals. In F. Bouchard and P. Huneman (Eds.) From Groups to Individuals: Evolution and Emerging Individuality (pp. 17-36). Cambridge, MA: MIT Press, Vienna Series in Theoretical Biology.

Goldstein, K. (1995). The Organism: a holistic approach to biology derived from pathological data in man. New York: American Book Company / New York: Zone Books. (A translation of Der Aufbau des Organismus, 1934)

Goodwin, B. (1994), How the Leopard Changed its Spots: The Evolution of Complexity. New York: Scribner's.

Grene, M. and Depew, D. (2004). The Philosophy of Biology: An Episodic History. Cambridge: Cambridge University Press.

Haber, M. (2013). Colonies Are Individuals: Revisiting the Superorganism Revival. In F. Bouchard, P. Huneman (Eds.) From Groups to Individuals: Evolution and Emerging Individuality (pp. 195-217). Cambridge, MA: MIT Press, Vienna Series in Theoretical Biology.

Haldane, J.S. D’Arcy Thompson, W., Chalmers Mitchell, P., Hobhouse, L.T. (1918). Symposium: Are Physical, Biological and Psychological Categories Irreducible?, Proceedings of the Aristotelian Society, Supplementary Volumes, Vol. 1: Life and Finite Individuality, 11-74. 
Hein, H. (1972). The endurance of the mechanism-vitalism controversy. Journal of the History of Biology, 5(1), 159-188.

Hull, D. (1981). Philosophy and biology. In G. Fløistad (Ed.), Contemporary philosophy: a new survey, vol. 2 (pp. 281-316). The Hague: M. Nijhoff.

Huneman, P. (2014). Formal Darwinism as a tool for understanding the status of organisms in evolutionary biology. Biol. Philos. DOI 10.1007/s10539-013-9419-6

Huneman, P., Rey, A.-L. (2007). La controverse Leibniz-Stahl dite Negotium otiosum. Bull. Hist. Épistém. Sci. Vie, 14(2), 213-238

Huneman, P., Wolfe, C.T., (Eds). (2010). The Concept of Organism: Historical, Philosophical, Scientific Perspectives, special issue of History and Philosophy of the Life Sciences (32:2-3). Ibrahim, A. (1999). Leibniz et la machine naturelle. Trame de la vie et chaine des vivants. Studia Leibnitiana, Supplementa 34: L'actualité de Leibniz: les deux labyrinthes, D. Berlioz, F. Nef (Eds.) (pp. 643-656). Stuttgart: Felix Steiner.

Jacob, F. (1970). La logique du vivant. Paris: Gallimard.

Kant, I. (1790). Kritik der Urteilskraft. In Gesammelte Schriften Herausgegeben von der Preußischen Akademie der Wissenschaften (Akademie-Ausgabe) 5, 165-486.

Keller, E.F. (2003). Making sense of life: Explaining biological development with models, metaphors, and machines. Cambridge, MA: Harvard University Press.

Kull, K. (2013). On the sphere of understanding: A note on Driesch. In S. Petrilli (Ed.), Writing, Voice, Undertaking (pp. 151-161). New York: Legas.

Lacépède, B.-G. de (1800). Histoire naturelle des poissons, II. Paris: Plassan.

Laubichler, M. (2000). The Organism is dead. Long live the organism! Perspectives on Science, 8(3), 286-315.

Leibniz, G.W. (1961). Opuscules et fragments inédits de Leibniz, ed. L. Couturat. Reprint, Hildesheim: Georg Olms.

Leibniz, G.W. (1978). Die Philosophischen Schriften, ed. G.J. Gerhardt, 7 vols. Reprint, Hildesheim: Georg Olms.

Leibniz, G.W. (1999). Sämtliche Schriften und Briefe, 6. Reihe: Philosophische Schriften, 16771690. Berlin: Akademie Verlag.

Lennox, J.G. (2001). Aristotle's Philosophy of Biology: Studies in the Origins of Life Science. Cambridge: Cambridge University Press.

Loeb, J. (1964). The mechanistic conception of life [1912]. In idem, The Mechanistic conception of life, Ed. D. Fleming (pp. 5-34). Cambridge, Mass.: Harvard University Press.

McLaughlin, P. (2002). Naming biology. Journal of the History of Biology, 35, 1-4. 
Machery, E. (2012) Why I stopped worrying about the definition of life... And why you should as well. Synthese, 185, 145-164. doi: 10.1007/s11229-011-9880-1

Ménuret de Chambaud, J.-J. (1765). CEconomie Animale (Médecine). Encyclopédie ou Dictionnaire raisonné des arts et des métiers, (Eds.) D. Diderot \& J. D’Alembert, vol. 11 (pp. 360366). Paris: Briasson. Reprint, Stuttgart/Bad Cannstatt: Frommann, 1966.

Modrak, D. (1996). Aristotle's Epistemology: One or Many Theories? In W. Wians (Ed.), Aristotle's Philosophical Development (pp. 151-170). Lanham, MD: Rowman \& Littlefield.

Morange, M. (1997). A History of Molecular Biology, trans. M. Cobb. Cambridge, Mass.: Harvard University Press.

Moreno, A. \& Mossio, M. (forthcoming). The autonomy of living systems: a philosophical enquiry into biological organization. Dordrecht: Springer.

Mossio, M., Moreno, A. (2010). Organisational closure in biological organisms. History and Philosophy of the Life Sciences, 32(2-3), 269-288

Nachtomy, O., Shavit, A., Smith, J.E.H.S. (2002). Leibnizian Organisms, Nested Individuals, and Units of Selection. Theor. Biosci., 121, 205-230.

Nagel, E. (1961) The Structure of Science. New York: Harcourt Brace \& World.

Needham, J. (1930). The Sceptical Biologist. New York: W.W. Norton.

Noppeney, U. (2001). Kurt Goldstein: a philosophical scientist. Journal of the history of the neurosciences, 10(1), 67-78.

Olson, E. (1997). The Human Animal: Personal Identity without psychology. Oxford: Oxford University Press.

Pepper J., Herron M. (2008). Does biology need an organism concept? Biol. Rev., 83, 621-627. Peterson, E. (2010). Finding Mind, Form, Organism, and Person in a Reductionist Age, PhD, 2 vols., Program in History and Philosophy of Science, University of Notre Dame.

Peterson, E. (2012). "Neither camp will have me": Lloyd Morgan, Needham, Woodger, and the early-20 ${ }^{\text {th }}$ century attempt to devitalize holism. Presentation at workshop on 'Hasard, holisme et réductionnisme dans les sciences de la vie', Paris, ENS, Centre Cavaillès, May 2012.

Pradeu T. (2012). The Limits of the Self: Immunology and Biological Identity, trans. E. Vitanza. New York: Oxford University Press.

Queller D.C., Strassmann, J.E. (2009). Beyond society: The evolution of organismality. Philos. Trans. Roy. Soc. Lond. B Biol. Sci., 364, 3143-3155.

Rheinberger, H.J. (1997a). Towards a History of Epistemic Things: Synthesizing Proteins in the Test Tube. Stanford: Stanford University.

Rheinberger, H.J. (1997b). Experimental Complexity in Biology: Some Epistemological and Historical Remarks. Philosophy of Science, 64, 245-254. 
Rheinberger, H.J. (1998). Experimental Systems, Graphematic Spaces. In T. Lenoir (Ed.), Inscribing science: scientific texts and the materiality of communication (pp. 285-303). Stanford: Stanford University Press.

Rosenberg, A. (1989) From Reductionism to Instrumentalism? In M Ruse (Ed.), What the Philosophy of Biology Is. Essays for David Hull (pp. 245-262). Dordrecht: Kluwer.

Ruse, M. (1989). Do Organisms Exist? American Zoologist, 29(3), 1061-1066

Ruyer, R. (1946). Éléments de psycho-biologie. Paris: PUF.

Ruyer, R. (1952). Néo-finalisme. Paris: PUF.

Schiller, J. (1978). La notion d'organisation dans l'histoire de la biologie. Paris: Maloine.

Schlanger, J. (1971). Les métaphores de l'organisme. Paris: Vrin.

Sober, E. (2003). Philosophy of Biology. In N. Bunnin (Ed.), Blackwell Companion to Philosophy, $2^{\text {nd }}$ revised edition (pp. 317-344). London: Blackwell.

Star, S.L., Griesemer, J.R. (1989). Institutional Ecology, 'Translations', and Boundary Objects: Amateurs and Professionals in Berkeley's Museum of Vertebrate Zoology, 1907-1939. Social Studies of Science, 19, 387-420.

Sterelny, K., Griffiths, P. (1999). Sex and Death: An Introduction to Philosophy of Biology. Chicago: University of Chicago Press.

Toepfer, G. (2013). Coming to Terms with Holism: Minimalistic Conceptual Tools for Describing and Explaining Holistic Systems in Biology. Presentation at ISHPSSB, Montpellier.

Turner J.S. (2006). Termite Mounds as Organs of Extended Physiology. Online at http://www.esf.edu/efb/turner/termite/termhome.htm. Consulted June 15, 2013.

Turner, J.S. (2007). The Tinkerer's Accomplice: How Design Emerges From Life Itself. Cambridge, Mass.: Harvard University Press.

Turner, J.S. (2013). Homeostasis and the forgotten vitalist roots of adaptation. In S. Normandin and C.T. Wolfe (Eds.), Vitalism and the scientific image in post-Enlightenment life science, 18002010 (pp. 271-291). Dordrecht: Springer.

Uexküll, J. von (1926). Theoretische Biologie. Berlin: J. Springer.

von Uexküll, J. (2010) A Foray Into the Worlds of Animals and Humans, with A Theory of Meaning (1934), trans. J D. O'Neil. Minneapolis: University of Minnesota Press.

Vicq-d'Azyr, F. (ed.) (1808). Encyclopédie méthodique ou par ordre des matières: Médecine, par une société de médecins, vol. 8. Paris: Veuve Agasse.

Wiggins, D. (2001). Sameness and Substance Renewed. Cambridge: Cambridge University Press. Wolfe, C.T. (2004). La catégorie d'organisme' dans la philosophie de la biologie. Retour sur les dangers du réductionnisme. Multitudes, 16, 27-40, online version at <http://multitudes.samizdat.net/spip.php?article1370>, Consulted June 152013 
Wolfe, C.T. (2006). Agrégat. In J.-Cl. Bourdin, C. Duflo et al. (Eds.), L'Encyclopédie du Rêve de D'Alembert. Paris: Éditions du CNRS.

Wolfe, C.T. (2010). Do organisms have an ontological status? History and Philosophy of the Life Sciences, 32(2-3), 195-232

Wolfe, C.T. (2011). Why was there no controversy over Life in the Scientific Revolution? In V. Boantza and M. Dascal (Eds.), Controversies in the Scientific Revolution (pp. 187-219).

Amsterdam: John Benjamins.

Wolfe, C.T. (forthcoming 2014a). Teleomechanism redux? Functional physiology and hybrid models of Life in early modern natural philosophy. Gesnerus, special issue: Entre mécanisme et téléologie. Anatomie, physiologie et philosophie des fonctions (seizième/dix-huitième siècles). Wolfe, C.T. (forthcoming 2014b). Holism, organicism and the risk of biochauvinism. Verifiche, 48(1-4)

Wolff, C.F. (1966). Theorie von der Generation; Theoria generationis [1764]. Hildesheim: Georg Olms. 